\title{
Waarop is sy voetstukke ingesink? - 'n Besinning oor die skepping en die big bang
}

L C Bezuidenhout

\section{ABSTRACT}

Upon what were the foundations of it fastened? Reflections on creation and the big bang

Through the ages the debate between theology and the natural sciences concerning the origin of the universe was turbulent. Today the big bang theory is almost generally accepted in scientific circles. In this article the debate between theology and science is evaluated critically. The theological implications of the big bang theory is discussed and the relevance of the cosmogony in Genesis 1 for a modern society is evaluated. Biblical models and scientific models of the birth of the cosmos do not have to be in conflict with each other.

\section{INLEIDING: DIE RELEVANSIE VAN BESINNING OOR DIE BEGIN}

In die Bybel sowel as in die moderne wetenskap word daar besin oor die begin. Hierdie besinning is nie net akademies van aard nie, maar insig ten opsigte van die begin help die mens om dit wat bestaan beter te begryp. Die mens wil homself oriënteer ten opsigte van sy wêreld. Die mens het ook die inherente behoefte om sy wêreld te beheer. Die mens se beheer oor sy wêreld staan in 'n direkte verhouding tot die mate waarin hy sy wêreld verstaan. In die proses om te verstaan, skep die mens modelle as verwysingsraamwerk waarbinne die wêreld verstaan word. Modelle se waarde word bepaal deur hul funksionaliteit.

Tans lyk dit asof daar botsings is tussen wetenskaplike modelle van die begin en Bybelse modelle van die begin. 'n Mens kan saam met Peacocke stem wanneer hy sê daar behoort 'n dialoog en "kon-sonansie" te wees tussen religieuse modelle en wetenskaplike modelle. Albei modelle moet meespreek tot die mens se geïntegreerde werklikheidsverstaan. Die modelle kan nooit identies wees nie. Peacocke mak die gevatte opmerking dat as die teologie vandag met die wetenskap trou, is dit môre 'n weduwee $^{1}$. In hierdie artikel word krities gekyk na die aard van hierdie modelle en die verhouding tussen die modelle. Is alle natuurwetenskaplike modelle aanvaarbaar vir die gelowige? Hoe moet Bybelse modelle verstaan word? 
Op watter manier kan Bybelse modelle "saamklink" met wetenskaplike modelle? In hierdie artikel word krities gekyk na hierdie vrae. Daar word 'n moontlike oplossing aan die hand gedoen hoe die moderne gelowige kan deelneem aan die natuurwetenskaplike debat oor die ontstaan, maar ter selfdertyd sy geloofsnaïwiteit behou.

Vanweë die beperkinge op 'n artikel soos hierdie, kan alle relevante sake nie bespreek word nie - 'n seleksie moes gemaak word. In hierdie artikel word die gesprek beperk tot kosmogonieë, dit wil sê modelle wat die begin van die kosmos verklaar. Die ontwikkeling van die mens is 'n baie interessante saak wat nie hier aangeraak word nie. Daar word ook op die kosmogonie van Genesis 1 gefokus, alhoewel daar verskeie ander kosmogonieë in die Bybel is.

\section{WETENSKAPLIKE MODELLE VAN DIE ONTSTAAN VAN DIE KOSMOS EN TEOLOGIESE REAKSIE DAAROP}

Daar is talle publikasies oor die verband tussen teologie en natuurwetenskap. Dit is egter moeilik om goeie teoloë te vind wat ook insig het in ontwikklinge op die natuurwetenskaplike gebied. Tog is daar ' $n$ paar persone wat uitgesonder kan word. 'n Persoon wat hom toelê op die verhouding tussen moderne natuurwetenskap en teologie is Arthur Peacocke. Sy gebiede van spesialisasie is fisiese biochemie en teologie. Cornél du Toit gee 'n goeie beskrywing van Peacocke se bydrae tot die gesprek tussen wetenskap en religie ${ }^{2}$. Hy het in Suid-Afrika opgetree tydens die South African Science and Religion Forum in 1995. Die strekking van sy bydraes op hierdie kongres is saamgevat in die publikasie "God and science. A quest for Christian credibility" 3 . Hierdie lesings en publikasie bou voort op die substansiële publikasie "Theology for a scientific age. Being and becoming - natural, divine and human" 4 . Peacocke is ook redakteur van ' $n$ bundel essays oor die verband tussen wetenskap en teologies. Hierdie bundel bevat goeie bydraes van teoloë, filosowe, sosioloë en 'n natuurwetenskaplike.

Peacocke haal in sy boek "God and science - a quest for Christian credibility" 6 Clifford Longley aan in The Times van 15 Februarie waar hy sê:

What most characterises the decline of faith in Britain is the perceived loss of credibility of religious belief, because it seems to have no foothold in a philosophical world view where the whole of reality can be encompasses by science. 
Hierdie toestand behoort vir enige gelowige kommerwekkend te wees. Peacocke beywer hom juis vir die herstel van Christelike geloofwaardigheid. 'n Christen behoort saam te praat oor die realiteit, ook oor die fisiese realiteit. Peacocke beskou sy benadering as "kritiese realisme". Ander navorsers wat hulle in hierdie kamp skaar, is Ian Barbour, Janet Soskice en John Polkinghorne. Hulle beklemtoon die kontinuïteit tussen wetenskap en teologie as dissiplines wat die werklikheid beskryf. Teologiese leerstellings kan aangepas word indien nodig. 'n Leerstelling wat direk in stryd is met gegewens wat natuurwetenskaplik vasgestel is, is nie meer houdbaar nie ${ }^{7}$.

Langdon Gilkey sien die verhouding tussen teologie en wetenskap anders. Hy lê meer klem op die eiesoortigheid van elke benadering. In teologie is mitologiese taal onontbeerlik. Dit het 'n eie karakter en is multivalent. Die mitologiese taal handel oor laaste vrae en eksistensiële aspekte van die werklike lewe soos die sin en doel van die lewe ${ }^{8}$. Selfs die nuwe wetenskap bedien homself van mites, soos die geloof dat die mens in staat is om alles te verstaan en sin te gee aan die werklikheid?.

Die Skotse teoloog T F Torrance beskou teologie as 'n wetenskap soortgelyk aan ander wetenskappe. Hy toon sekere parallelle aan tussen die ontwikkelinge in teologie en die ontwikkelinge in die natuurwetenskap. Albei dissiplines bestudeer die werklikheid, alhoewel teologie 'n dieper werklikheid bestudeer. Die teologie moet tred hou met die ontwikkeling in die natuurwetenskap om die rasionele patrone te ontdek wat God daar geplant het - al dien dit net om God as Skepper te loof en te aanbid. Beide teologie en natuurwetenskap is geïnteresseerd in die feit dat die kosmos nie deur natuurwette alleen bepaal word nie. Hierdie raakpunt moet ontgin word. Teologie het die taak om aan natuurwetenskaplikes die transendente verhouding te verduidelik wat die Skepper het met die kosmos wat Hy skep en onderhou ${ }^{10}$.

Willem Drees is 'n Nederlandse navorser in teoretiese fisika wat na sy kwalifikasie in fisika ook in die teologie gestudeer het. Sy boek "Beyond the big bang. Quantum cosmologies and God" gee goeie inligting ten opsigte van die huidige stand van sake in die teoretiese fisika. Hy béspreek verskeie modelle krities. Hy bespreek die standpunt van verskeie teoloë ten opsigte van hierdie modelle en gee ook sy eie opinie oor die verhouding tussen natuurwetenskap en teologie ${ }^{11}$. Hy beskou sy eie posisie as 'n soeke na teologie in 'n kritiese koherensie met wetenskap'2. Drees maak die nugter stelling dat daar geen wetenskaplike gegewens is wat die bestaan van God ondersteun of weerspreek nie ${ }^{13}$. 


\subsection{Die verlede}

In die Ou Testament word veskillende modelle aangebied om die begin van die wêreld te verstaan. In die vroeë Jodendom en Christendom was die verstaan van die begin onproblematies. Die verskille tussen die Bybelse modelle is nie op die spits gedryf nie - die weergawe in Genesis 1 is beskou as die geldige model vir die begin. Daar was ook nie 'n diskrepansie tussen hierdie en naturwetenskaplike modelle van die begin nie dit was beskou as die enigste geldige verstaan van die begin. Tot vandag toe word dit so gesien in sommige fundamentalistiese strominge.

Augustinus het geglo dat daar ook 'n rasionele begronding van die skepping gegee moet word. Sy eerste poging om 'n kommentaar op Genesis te skryf, is nie deurgevoer nie. Tog het hy in $415 \mathrm{nC}$ 'n werk geskryf in twaalf boeke met die titel "De Genesi ad litteram". Hierin het hy die skepping soos dit in Genesis voorkom in verband gebring met die wetenskap van sy tyd. Dit het sekere probleme opgelewer. Die verdeling van die skepping in ses dae soos dit in Genesis voorkom, was nie aanvaarbaar in terme van die opvattinge van Augustinus se tyd nie. Hy moes dit metafories interpreteer. Augustinus het hom dus gewend tot die strategie om gegewens in die Bybel wat nie "klop" nie, metafories te interpreteer ${ }^{14}$.

Hier vind ons ' $n$ benadering wat vandag nog populêr is. Tog is hierdie benadering vol voetangels. Volgens watter maatstaf word vasgestel of Bybelse gegewens "klop"? Augustinus gee altyd voorrang aan die letterlike verstaan van die Bybel. Volgens hom is die "ligste" woord van God beter as die "swaarste" woord van die mens, behalwe as laasgenoemde bo alle twyfel bewys kan word. Indien daar bewys kan word dat ' $n$ ander voorstelling, wat in konflik is met die Bybelse voorstelling, korrek is, kom 'n ander strategie in werking. Wetenskap is ook deur God aan die mens gegee en kan nie in konflik wees met die Woord nie. In so 'n geval word aangeneem dat die Bybelse voorstelling nie reg verstaan is nie, of dat dit figuurlik geïnterpreteer moet word ${ }^{15}$. Hierdie strategie kom net in uitsonderlike gevalle in werking. Volgens Augustinus is die kosmogonie van die Bybel deel van die goddelike openbaring en moet dit normaalweg so aanvaar word. Natuurwetenskaplike teorieë wat nie bo alle twyfel bewys kan word nie, mag dus nooit voorrang kry bo die letterlike verstaan van die Bybel nie. Dit is 'n baie konserwatiewe standpunt.

Augustinus maak ook voorsiening daarvoor dat die Bybel nie uitsluitsel gee oor alle kwessies rondom die skepping van die wêreld nie. Daar is nie by hom twyfel dat die Bybelskrywers hierdie kennis gehad het nie, maar hulle het dit nie nodig geag om al die kennis aan ons deur te gee nie. In Augustinus se tyd was daar blykbaar verskille oor die vraag of die 
hemel soos 'n sfeer is met die aarde in die kern daarvan en of die hemel soos 'n skyf bokant die aarde is. Volgens Augustinus het die Gees van God wat in die Bybelskrywers werk, hierdie inligting nie as relevant vir die verlossing van die mens beskou nie, en dit dus nie aan die Bybellesers deurgegee nie ${ }^{16}$. Hierdie argument gee perspektief op die fokus van die Bybel en onderskei die terrein van die Bybel van die terrein van die natuurwetenskap. Dit is tot vandag toe 'n nuttige argument. Tog is daar 'n kontradiksie tussen Augustinus se argumente. Indien verlossing die fokus van die Bybel is, waarom moet die kosmogonie van die Bybel ooit letterlik opgeneem word? Die vraag is tot vandag toe aktueel.

In die Middeleeue het die Joodse filosoof Maimonides (1135-1204) byna dieselfde strategie gevolg as Augustinus. Indien daar bo alle twyfel bewys is dat ' $n$ ander model as die Bybelse model aanvaar moet word, behoort die Bybelse model allegories geïnterpreteer word ${ }^{17}$. Hy het daarna gestreef om die Griekse filosofie en die Hebreeuse Bybel met mekaar te versoen. Hy het egter in een opsig radikaal verskil van die Aristoteliese fisika. Volgens Aristoteles het nòg materie, nòg tyd 'n begin. Dit sou volgens Maimonides in stryd wees met die model in Genesis 1 waar 'n temporele begin van die heelal veronderstel word. Die Aristoteliese fisika het ook onder Christene veld gewen in die Middeleeue. Al is dit veroordeel deur Franse biskoppe in 1277, het die Aristoteliese model gewild gebly. Die Vierde Lateraanse Verdrag (1215) het bepaal dat dit 'n geloofsfeit is dat die heelal 'n absolute begin het. Hierdie saak word weer in die moderne tyd gedebateer.

In die veertiende eeu was daar 'n hewige debat oor die vraag: Lei die beginsels van die fisika tot noodwendige gevolge (soos die verdedigers van die Aristoteliese benadering glo), of is daar ' $n$ verskeidenheid van moontlikhede (soos die nominaliste geglo het)? Volgens die nominalistiesvoluntaristiese benadering is daar nie 'n noodwendigheid in die natuurwetenskappe nie. Dit sou God se vryheid van keuse inperk. Daar is 'n veelheid van gevolge moontlik. God kies egter om 'n bepaalde gevolg te laat realiseer ${ }^{18}$. ' $n$ Soortgelyke debat vind weer in die moderne tyd plaas.

Copernicus se siening oor die kosmos het hom in botsing gebring met die kerk. Hy het 'n kerklike amp beklee in Pole. In Mei 1514 het hy sy idees oor die kosmos versprei in 'n dokument genoem Commentariolus. Hierdie dokument is in die geheim versprei, aangesien hy bang was vir die reaksie van die kerk. Copernicus se insigte is eers heelwat later gepubliseer as "De revolutionibus orbium coelestium" (1543). Hiervolgens is die aarde nie meer die sentrum van die kosmos nie, maar die son. Die aarde draai om sy eie as en is in 'n wentelbaan om die son. Hierdie model sou 
die rotasie van die hemel, die jaarlikse beweging van die son deur die diereriem en bewegings van die planete beter verklaar. Op daardie stadium was dit vir die kerk belangrik om te glo dat die aarde in die middel van die kosmos is. Volgens die kerk is die mens die kroon en die doel van die skepping. Dit moet ook gereflekteer word in 'n model waar die aarde die sentrum van die kosmos is.

Galileo het self 'n dilemma ondervind. Sy kosmologie het hom in konflik gebring met die kerk van die sewentiende eeu. Hy wou bewys dat Copernicus se kosmologie nie in stryd is met die Skrif nie. In sy brief aan die Grafin Christina in 1615 haal hy Augustinus se argumente aan. Ten spyte van sy aandrang dat sintuiglike waarnemings en wiskundige bewyse nie onderwerp moet word aan Bybelse uitsprake nie, het die Roomse Kerk 'n edik vroeg in 1616 teen Galileo uitgevaardig. Nadat 'n vriend van Galileo, Maffeo Barberini, pous geword het, is hy toegelaat om 'n boek te skryf oor die Ptolemeïese en Copernicaanse modelle. Na verskyning van sy boek (Dialogo) in 1632 is hy na Rome ontbied en deur die Inkwisisie skuldig bevind. Hy is tot lewenslange tronkstraf gevonnis weens kettery. Sy boek is verban en geen werke van hom mag weer gepubliseer word nie. Sy vonnis is darem versag tot huisarres.

Galileo het die wêreld bedag gemaak op die behoefte van wetenskaplikes om in vryheid hulle bevindinge bekend te maak. Galileo het die gesag van die Bybel erken. Hy het by Augustinus aangesluit maar Augustinus se standpunt verder uitgebrei. Volgens Galileo is daar sekere verskynsels waaroor die natuurwetenskap in beginsel geen uitspraak kan maak nie. Ten opsigte van hierdie aspekte moet Bybelse uitsprake onvoorwaardelik aanvaar word. Ten opsigte van verskynsels waaroor natuurwetenskap in beginsel uitsprake kan maak, behoort dit toegelaat te word. Galileo het ook 'n meer liberale houding oor die gesag van die Skrif. Volgens hom rus die onus op die teoloog om te bewys dat Bybelse modelle letterlik opgeneem moet word. Hy sluit aan by Augustinus dat die Bybel fokus op die redding van die mens en nie op kosmologiese modelle nie. Kosmologiese modelle is bedoel om te kommunikeer met die mense van die Bybelse tyd en is dus neutraal ten opsigte van "moderne" natuurwetenskap, tensy dit iets oor verlossing wil kommunikeer ${ }^{19}$. Hierdie siening is 'n meer toegeeflike benadering as Augustinus s'n en hou interessante moontlikhede in vir die moderne gelowige. Tog moet in gedagte gehou word dat Galileo se siening oor dinge waaroor die wetenskap uitsprake kan maak, baie verskil van die moderne siening.

Die sogenaamde "nuwe wetenskap" in die sewentiende eeu het ruimte gebied vir verskillende kosmogoniese modelle. Volgens Newton se 
meganika is die begrippe ruimte en tyd sonder ' $n$ begin, maar ook sonder inhoud. Skepping sou beteken dat God op 'n spesifieke tyd materie bring in 'n spesifieke ruimte. Gebeure op aarde toon 'n ontwikkeling. Volgens die tweede wet van termodinamika neig alle sisteme na 'n toestand van groter wanorde. Hierdie ontwikkeling het die Aristoteliese siening dat die kosmos van ewigheid af bestaan en in die toekoms sal bestaan, in onguns gebring. Sommige mense het gemeen dat Newton se meganika in stryd is met die Bybelse model. Leibniz het Newton gekritiseer oor die feit dat ruimte ewig is. Hoe kan dit in verband gebring word met die ewigheid van God ${ }^{20}$ ?

In sy boek "Kritik der reinen Vernunft" het Immanuel Kant aangetoon dat daar nie deur middel van die rede uitsluitsel gegee kan word oor die kwessie of die kosmos beperk is in tyd en ruimte nie ${ }^{21}$.

\subsection{Die huidige situasie}

Kosmologie soos ons dit vandag ken, het sy beslag gekry na die formulering van die algemene teorie van relatiwiteit en die kwantumteorie van materie, asook die ontdekking deur Hubble in 1929 dat die lig van ver afgeleë sterrestelsel skuif na die rooi kant van die spektrum. Lemaitre het tot die slotsom gekom dat die sterrestelsels uitmekaar beweeg vanuit 'n gemeenskaplike oorsprong. Die oorsprong is later deur Gamow genoem "Big Bang" 22. Die feit dat daar op grond van wetenskaplike bevindinge tot die slotsom gekom is dat daar 'n begin was vir die heelal, het Christene opgewonde gemaak oor die geldigheid van die Genesis 1 model soos dit tradisioneel verstaan word. In 1951 het Pous Pius wetenskaplikes bedank dat hulle die harmonie in die skepping openbaar wat die werk is van 'n alwyse God. Dit lyk asof God wag agter elke deur wat deur die wetenskap oopgemaak word ${ }^{23}$. Vir Pous Pius het dit nie gegaan om die versoening van wetenskaplike en Bybelse uitsprake nie - hy het die wetenskaplike uitsprake gesien as 'n bevestiging van Bybelse uitsprake. Materie het 'n begin en ' $n$ einde. Die begin kan nie uit materie self tot stand kom nie. Dit vereis, volgens die argument van Thomas van Aquinas, 'n Eerste Beweger $^{24}$. Gamow en Lemaitre was self nie gelukkig met die feit dat die pous die big bang-teorie sien as 'n bewys van die korrektheid van die Bybelse kosmogonie nie ${ }^{25}$.

In 1959 het die Amerikaanse teoloog Langdon Gilkey weer die aandag gevestig op die verhouding tussen die natuurwetenskap en Bybelse weergawes van die skepping deur sy publikasie "Maker of heaven and earth" 26. Die big bang-teorie is aanvanklik as spekulatief beskou en is nie deur almal ernstig opgeneem nie. Hy het egter daarop gewys dat daar 'n kategoriese verskil is tussen teologie en natuurwetenskap en dat dit nodig is om die eiesoortige mites te interpreteer wat in beide dissiplines voorkom. 
Robert Jastrow, self 'n agnostikus, het die volgende uitspraak gemaak in 'n lesing vir die American Association for the Advancement of Science (1978):

For the scientist who has lived by his faith of reason, the story ends like a bad dream. He has scaled the mountains of ignorance; he is about to conquer the highest peak; as he pulls himself over the final rock, he is greeted by a band of theologians who have been sitting there for centuries ${ }^{27}$.

Hierdie uitspraak is deur gelowiges baie gunstig ontvang, maar Jastrow het beslis nie dieselfde benadering as die pous nie. Hy het hiermee eintlik net bedoel dat die ontwikkeling in die moderne wetenskap naby kom aan die voorstelling dat die skepping skielik tot stand gekom het. Tot vandag toe kry natuurwetenskaplikes groot publisiteit onder gelowiges indien hulle uitsprake maak wat die gesag van die Bybel ondersteun. Sulke uitsprake voldoen nie altyd aan die eise van wetenskaplikheid nie.

Nadat die 3०K uitstraling in 1965 deur Penzias en Wilson ontdek is, het die big bang-teorie groot veld gewen ${ }^{28}$. Friedmann het voorspel dat daar mikrogolfuitstralings waargeneem sal word wat afkomstig is uit die big bang. Tydens die big bang is groot hoeveelhede lig uitgestraal. As gevolg van die uitbreiding van die heelal sal hierdie lig as so ver na die rooi kant van die spektrum verskuif het, dat dit net as mikrogolwe waarneembaar is ${ }^{29}$. Die feit dat mikrogolwe uit alle rigtings in die heelal gemeet kan word, bewys hierdie teorie as korrek.

Die big bang-teorie het 'n groot swakpunt gehad. Volgens die teorie het alles ontstaan uit 'n enkelvoudigheid wat aanvanklik nie ruimte beslaan het nie. Die grootskaalse eenvormigheid van die heelal strook met die opvatting dat dit uit 'n enkelvoudigheid ontstaan het. Tog toon die bestaan van sterrestelsels, sonne en planete bewys daarvan dat daar op sekere plekke 'n groter konsentrasie van materie is. Dit is alleen moontlik indien daar met die big bang 'n fluktuasie van energie was. Dit sou tot gevolg hê dat die kosmiese mikrogolfuitstraling wat vandag waargeneem word, ook 'n fluktuasie moes toon. Hierdie fluktuasie is inderdaad in 1992 waargeneem deur die COBE-sateliet (Cosmic Background Explorer) ${ }^{30}$. Vandag word die big bang-teorie algemeen aanvaar.

Stephen Hawking is genooi om in 1981 'n konferensie van die Jesuiete in die Vatikaan by te woon oor kosmologie. Die Rooms-Katolieke Kerk het kundiges uitgenooi om hulle van advies te bedien oor kosmologie. Dit is 'n totaal ander situasie as in die dae van Galileo. Aan die einde van 
die konferensie het die pous aan hulle gesê dat dit in orde is om die evolusie van die kosmos na die big bang te bestudeer, maar hulle mag nie die big bang self bestudeer nie aangesien dit die skeppingswerk van God is. Hierdie gesprek met die pous het ' $n$ indruk gemaak op Hawking. In die boek "A brief history of time" hanteer hy die religieuse kwessie met sensitiwiteit. Ter wille van die leser verwys hy na God, alhoewel die religieuse aspek nie werklik deel vorm van die model wat hy voorstaan nie. Vir Hawking is dit nie ongehoord om vrae te vra oor die oorspronklike toestand van die heelal nie - hy kan nie anders as om van die pous te verskil nie. Hy redeneer soos volg:

Science seems to have uncovered a set of laws that, within the limits set by the uncertainty principle, tell us how the universe will develop with time, if we know its state at any one time. These laws may have originally been decreed by God, but it appears that he has since left the universe to evolve according to them and does not now intervene in it. But how did he choose the initial state or configuration of the universe! What were the "boundary conditions" at the beginning of time?

One possible answer is to say that God chose the initial configuration of the universe for reasons that we cannot hope to understand. This would certainly have been within the power of an omnipotent being, but if he had started it off in such an incomprehensible way, why did he choose to let it evolve according to laws that we could understand! The whole history of science has been the gradual realisation that events do not happen in an arbitrary manner, but that they reflect a certain underlying order, which may or may not be divinely inspired. It would be only natural to suppose that this order should apply not only to the laws, but also to the conditions at the boundary of space-time that specify the initial state of the universe ${ }^{31}$.

Die veertiende-eeuse debat oor die noodwendigheid al dan nie van natuurwetenskaplike beginsels het skielik weer relevant geraak. In Newton se kosmos was daar 'n sterk element van noodwendigheid. Die natuurwetenskaplike beginsels het die verband tussen oorsaak en gevolg gedikteer. Tog was die verspreiding van materie in die kosmos en die vorm van die kosmos nie noodwendig nie. Dit is verrassend dat die teoloog Pannenberg 'n teologiese probleem sien in die noodwendigheid in Newton se model, en veral die eerste wet van Newton wat soos volg lui: Elke voorwerp bly in 'n 
toestand van rus of van univorme beweging in 'n reguit lyn, tensy dit gedwing word om daardie toestand te verander deur kragte wat daarop inwerk. (Dit was in teenstelling met die Aristoteliese opvatting wat in die middeleeue oorheers het, naamlik dat voorwerpe alleen beweeg indien 'n bepaalde krag die beweging veroorsaak. Wanneer 'n perd van 'n wa losgemaak word, sal daardie wa dus tot stilstand kom) ${ }^{32}$. Volgens Pannenberg impliseer Newton se wet dat daar nie ruimte is vir God se onderhouding van die natuur nie. Dit lei tot die ongelukkige strategie dat Christene soek na "gapings" in die natuurlike prosesse om God se ingryping in daardie gapings te sien (God of the gaps). Volgens hom tree God in vryheid op wanneer $\mathrm{Hy}$ die fondamente van die skepping daarstel sowel as in die daaropvolgende gebeure. Daar is dus sprake van 'n "voortdurende skepping" ${ }^{33}$. Alhoewel Torrance nie so radikaal is soos Pannenberg in sy benadering nie, is hy baie gesteld op die feit dat alles nie deur natuurwette gedikteer word nie. Die element van "kans" laat ruimte vir die betekenis van gebed en konsepte soos verlossing en inkarnasie ${ }^{34}$.

In Einstein se kosmos was daar relatiwiteit in die sin dat daar met geen absolute waardes gewerk word nie, behalwe die snelheid van lig, tog wou Einstein nie toegee dat daar 'n element van "kans" in die kosmos bestaan nie. Die element van "kans" kom in 'n sekere sin na vore in die big bang-teorie. Na die big bang kan 'n mens aanvaar dat daar 'n wetmatigheid kan wees, maar daar is geen natuurwetenskaplike beginsel wat die big bang as sodanig kan verklaar in terme van iets ander wat dit voorafgegaan het nie. Daar is dus 'n kans dat die big bang anders kon wees as wat dit was $^{35}$.

Die element van "kans" kom ook sterk na vore in die kwantummeganika. Volgens hierdie model is die optrede van partikels nie volledig voorspelbaar nie, 'n mens kan hoogstens van waarskynlikheid praat. Wanneer die waarskynlike beweging van 'n partikel bepaal word, word die som van al die moontlikhede in ag geneem. Materie het ook golfeienskappe. Dit kan gebeur dat 'n partikel ter selfdertyd meer as een pad volg of 'n pad volg wat volgens klassieke fisika nie moontlik is nie. Kwantummeganika is streng gesproke net van toepassing op die mikrokosmos, maar dit het ook implikasies vir die makrokosmos ${ }^{36}$. In die verlede is onvoorspelbaarheid deur mense aangegryp om vir God 'n plek te gee in die verloop van sake (God of the gaps). Namate die "gapings" deur wetenskaplike kennis gevul word, word die domein van God in die wetenskap ongelukkig al kleiner en kleiner. So 'n praktyk moet afgewys word ${ }^{37}$. In die kwantummeganika is daar nou ' $n$ inherente onvoorspelbaarheid, daar is dus permanente "gapings" in ons vermoë om die gang van sake te 
verstaan en te voorspel. Sou God se ingryping pas in hierdie gapings? Peacocke oorweeg hierdie moontlikheid. Daar is nie die gevaar dat hierdie gebied deur wetenskaplike kennis sal verklein nie. Al is die fluktuasies in hierdie terrein vir die mens in beginsel onvoorspelbaar, is dit aan God bekend. Wanneer God op hierdie terrein die proses beheer, sal dit nie in stryd wees met wetenskaplike beginsels nie ${ }^{38}$.

Een argument om die bestaan van God in te sluit by die big bangmodel, is om te aanvaar dat die oorspronklike toestand van die heelal baie fyn vasgestel moes word om te lei tot die ontwikkeling van mense. In die lig van die veelheid van chaotiese toestand wat moontlik was, is dit moeilik om te verklaar waarom alles so ordelik verloop het verklaar tensy 'n mens veronderstel dat die Skepper daarvoor verantwoordelik is ${ }^{39}$. Hierdie argument word dikwels gebruik deur natuurwetenskaplikes wat die bestaan van God wil bewys. Dit lyk asof 'n geordende heelal tot stand gekom het om die omstandighede te skep waarin mense kan lewe. Sommige verwys na hierdie waarneming as die antropiese of mensgerigte beginsel. So 'n beginsel kan nie in die natuurwetenskappe geld as verklaring nie. Dit is eerder ' $n$ teleologiese beginsel (gerig op die doel) as ' $n$ kousale beginsel (gerig op die oorsaak) ${ }^{40}$.

Daar is meer begrip vir die feit dat die geheel van 'n sisteem 'n invloed uitoefen op die dele daarvan. Peacocke ondersoek hierdie aspek as 'n moontlikheid om God se ingryping te verduidelik. 'n Proses word nie net kousaal bepaal deur toestande en gebeure op die laer vlakke nie - dit is asof inligting van die hoër vlakke gebeure op die laer vlakke beïnvloed. Indien die hele skepping "in God" bestaan, impliseer dit volgens Peacocke dat die wil van God ook binne hierdie paradigma die verloop van gebeure bepaal. Peacocke vergelyk hierdie proses met die interaksie in 'n mens tussen sy denke en sy fisiese prosesse. Soos gedagtes fisies prosesse kan beheer in die liggaam, so kan God ook invloed uitoefen op die verloop van gebeure $^{41}$.

Die oënskynlike beweging van chaos na orde kan ook natuurwetenskaplik verklaar word. Volgens die sogenaamde "swak antropiese" beginsel (Hawking se terminologie), kan 'n mens aanvaar dat in 'n oneindig groot chaotiese heelal daar 'n kans is dat sommige gedeeltes georden sal wees. Ons moet dus nie verbaas wees om net geordenheid om ons te sien nie - dit is net in gebiede soos hierdie waar intelligente wesens kon ontwikkel om dit waar te neem. Hawking vergelyk dit met 'n ryk persoon wat in 'n welvarende gebied bly - hy moenie verbaas wees indien hy nie armoede sien nie ${ }^{42}$. ' $n$ Ander manier om daarna te kyk is dat die vinnige uitbreiding van die heelal die onegalighede uitgestryk het soos die voue in 'n ballon verdwyn wanneer dit opgeblaas word. 
Die kerk se opgewondenheid oor die big bang-teorie het gestaan en geval by die insig dat die heelal 'n begin het. Die kerk onthou nog die middeleeuse stryd teen die Aristoteliese kosmologie wat 'n ewige kosmos veronderstel. Nou is dit nie meer van selfsprekend dat die big bang-teorie ' $n$ absolute begin veronderstel nie. Indien die heelal genoeg materie bevat, sal die aantrekkingskrag tussen materie die snelheid van die materie so teenwerk, dat die uitsetting uiteindelik tot stilstand kom (daar is egter 'n kans dat daar nie genoeg materie is nie). Daarna sal die heelal begin om in te krimp totdat dit uiteindelik eindig in 'n big crunch waar die heelal terugkeer tot 'n enkelvoudigheid ${ }^{43}$. Dit is teoreties moontlik dat so 'n big crunch gevolg kan word deur 'n volgende big bang. In so 'n geval het ons 'n pulserende heelal wat ons terugbring by die Aristoteliese opvatting van 'n heelal sonder begin of einde! Dan sal die kerk weer in dieselfde dilemma wees as in die middeleeue.

Hawking stel 'n ander moontlikheid voor waarin die heelal beperk is maar sonder begin of einde. Einstein het reeds die begrippe tyd en ruimte in een model met vier dimensies saamgebind wat hy ruimte-tyd noem (drie dimensies in ruimte en een dimensie in tyd). Ons kan ons nie ' $n$ vierdimensionele model voorstel nie. Ter wille van die argument kan ruimte beperk word tot twee dimensies ('n plat vlak) en kan tyd as die derde dimensie voorgestel word wat loodreg op hierdie vlak is. Wanneer die uitbreiding van die kosmos na die big bang gereduseer word tot twee dimensies, kan dit gesien word as die rimpeling op die oppervlak van 'n dam wanneer 'n klip in die water gegooi word. Wanneer dit op 'n grafiek voorgestel word met 'n vertikale tydsas, sal daar heel onder 'n punt wees, bokant dit 'n klein sirkel, nog boontoe 'n groter sirkel, ensovoorts. Indien die kosmos weer gaan inkrimp, sal dit op 'n stadium 'n skyf vorm met maksimum grootte en dan weer stelselmatig verklein totdat dit eindig in 'n punt heel bo. Dit sou lyk soos die aardbol met sy breedtegraadlyne. Die twee pole sou die big bang en die big crunch verteenwoordig. Die reguit lyn van die een pool na die ander is dan die tydsverloop. Daar moet net onthou word dat hierdie model ' $n$ redusering is tot drie dimensies - in werklikheid beslaan ruimte reeds drie dimensies en voeg tyd ' $n$ vierde dimensie by. Op die oog af het hierdie model duidelike grense - 'n begin by die een pool en 'n einde by die ander pool. Reële tyd loop lineêr van die een pool na die ander. Die model is egter nie so eenvoudig nie. Wanneer daar gedink word aan 'n model waarvolgens die heelal verstaan kan word, moet die effek van gravitasie op die ruimte-tyd-matriks en die dinamika van kwantummegani$\mathrm{ka}$ in ag geneem word. In kwantummeganika verloop gebeure nie eenduidig op 'n lineêre tydsas in 'n ruimte-tyd-matriks nie. Daar moet onthou 
word dat die ruimte-tyd-matriks as 'n eenheid beskou word waar tyd 'n dimensie is net soos die dimensies van ruimte. Hawking gebruik 'n konsep wat hy noem imaginêre tyd. Dit word so genoem na analogie van dit wat ons in wiskunde ken as komplekse getalle. Komplekse getalle het 'n imaginêre deel. Dit kan nie lineêr op 'n getallelyn aangedui word nie. In 'n model waar reële tyd vervang word met imaginêre tyd, is die vier dimensies gelykwaardig. Daar is nie 'n verskil tussen rigting in tyd en rigting in ruimte nie. Indien die ruimte-tyd-matriks ter wille van die argument gereduseer word tot 'n plat oppervlak soos 'n wêreldkaart, moet die volgende proses plaasvind: Dit word deur gravitasie verwring soos 'n wêreldkaart verwring word tot 'n geslote sfeer wanneer dit in 'n aardbol verander word. 'n Aardbol het nie rante nie. Wanneer 'n mens by die pole rondloop, merk jy nie 'n grens nie. Hierdie model impliseer dat die heelal nie ' $n$ begin of ' $n$ einde het nie ${ }^{44}$. Dit bring Hawking tot die slotsom dat 'n Skepper nie deur die model as noodsaaklik veronderstel word nie:

...But if the universe is really completely self-contained, having no boundary or edge, it would have neither beginning nor end: it would simple be. What place, then, for a creator? ${ }^{45}$

In terme van bostaande model is dit nie nodig om aan God 'n plek te gee in 'n wetenskaplike model van die ontstaan van die kosmos nie. Hierdie slotsom is nie so skokkend soos dit klink nie. Dit impliseer bloot dat die natuurwetenskaplike dimensie van die werklikheid beskryf kan word in terme van natuurwetenskaplike kategorieë. Die big bang-teorie ondersteun nie noodwendig die Christelike geloof nie, en die Christelike geloof ondersteun nie noodwendig die big bang-teorie nie ${ }^{46}$.

Peacocke glo egter dat die blote feit dat iets bestaan, begrond moet word. Volgens hom behoort daar een of ander Ground of Being veronderstel te word ${ }^{47}$.

\section{WETENSKAPLIKE EVALUASIE VAN BYBELSE KOSMO- GONIE $\ddot{E}$}

Alhoewel daar verskillende kosmogonieë op verskillende plekke in die Bybel is, bied Genesis 1 die mees programmatiese kosmogonie. In hierdie artikel word daar op Genesis 1 gekonsentreer, maar daar word ook na ander kosmogonieë verwys.

Wanneer 'n mens Genesis 1 en ander kosmogonieë reg wil verstaan, moet dit in die regte konteks geplaas word. Moderne Bybelse kritisisme het 
probeer om voorstellings krities teen die regte agtergrond te lees. Die konteks word 'n agtergrond waarbinne die teks as 't ware geraam word.

Hermann Gunkel het in 1895 'n publikasie die lig laat sien wat as 'n mylpaal beskou kan word in die godsdienshistoriese debat rondom die skepping, naamlik Schöpfung und Chaos in Urzeit und Endzeit ${ }^{48}$. Volgens Gunkel is die Babiloniese Chaoskampf tussen die skeppergod en die chaosmagte die oorsprong van die mitologiese simbole in die Bybel. Bernhard Anderson het hierop kommentaar gelewer in sy 1967 publikasie oor die mitologiese simbole in die skeppingsverhale ${ }^{49}$. Na Gunkel se publikasie is die literatuur van Ugarit ontdek in die jare 1920 tot 1933. Hierdie vondse, asook ander antieke literatuur wat sedertdien aan die lig gekom het, toon dat die mitologiese simboliek nie net tot die Babiloniese kultuur beperk was nie, maar dat dit algemeen voorgekom het in die antieke wêreld.

Israel het geput uit die mitologiese bronne van die Ou Nabye Ooste en is aangepas by Israel se etiese monoteïsme ${ }^{50}$. Die mitologiese aspek veronderstel ' $n$ ander modus van denke. In die boek "The intellectual adventure of ancient man" van $\mathrm{H}$ en H A Frankfort word die karakter van mitologiese denke netjies uiteengesit ${ }^{51}$. Mitologie is poëties van aard. Dit is 'n poging om reg te laat geskied aan 'n waarheid wat nie deur kliniese logika uitgedruk kan word nie. In die bestudering van die Bybelse gegewens oor die skepping moet rekening gehou word met die poëtiese karakter daarvan 52 .

Clifford en Collins ${ }^{53}$ identifiseer die volgende vier verskille tussen kosmogonieë in die Ou Nabye Ooste en moderne modelle:

* In die antieke tyd word die proses van skepping voorgestel na analogie van menslike aktiwiteite, soos byvoorbeeld die bou van 'n huis of modellering in klei, die oorwinning oor en dood van 'n vyand, ensovoorts.

* In die antieke tyd word die ontstaan of ordening van 'n gemeenskap in verband gebring met die skepping.

* In antieke tye is die kosmogonie voorgestel as 'n drama. Persone tree op en die gebeure word in 'n vorm van 'n verhaal vertel. Dit was in die antieke tyd moontlik om 'n paar verhale te hê as kosmogonieë sonder dat die verskille gesien is as kontradiksies.

* Ander standaarde word gestel aan antieke kosmogonieë. Dit is nie nodig om te klop met al die gegewens nie. Die waarde lê in die funksionaliteit van die kosmogonie en nie in die korrektheid van die feite nie. Dit spreek die verbeelding aan eerder as die logika. 


\subsection{Mitologiese voorstellings}

Die leser kan goeie bronne raadpleeg oor mitologie wat verband hou met Bybelse voorstellings. Gunkel gee in sy publikasie van 1895 'n goeie vergelyking tussen Bybelse voorstellings en Babiloniese voorstellings. Victor Matthews en Don Benjamin se "Old Testament parallels: Laws and stories from the Ancient East" 54 is 'n handige en populêre bron. Hier kan vertalings gelees word van verhale uit Mesopotamië, Egipte en Ugarit wat verband hou met Bybelse skeppingsvoorstellings. Agter in die boek word 'n bibliografie gegee van tekste in transkripsie en transliterasie. Pritchard se "Ancient Near Eastern texts relating to the Old Testament" bly steeds 'n goeie naslaanbron.

Gunkel toon aan dat die Chaoskampf 'n prominente element is van skeppingsvoorstellings. In Akkadiese literatuur kom dit voor as die geveg tussen Marduk en Tiamat, in Kanaänitiese literatuur as die stryd tussen Baäl en Jam en in Egiptiese literatuur as die verhaal van Ra en die slang. Dit is tipies van antieke literatuur om 'n veelheid van gode te veronderstel en om goddelike eienskappe aan elemente soos die aarde toe te ken. Antropomorfe voorstellings van gode kom ook algemeen voor in antieke literatuur. In die volgende paragrawe word aangetoon hoe hierdie verskynsels ook in die Bybel voorkom.

Gunkel se siening dat die Bybelse skeppingsvoorstellings teruggaan op 'n Babiloniese Vorlage, was 'n radikale standpunt vir sy tyd. Tog sien 'n mens naïwiteit in sy slotsom, naamlik dat die voorsienende wil van God geopenbaar word in die evolusie van Israel se religie ${ }^{55}$.

\subsubsection{Die Chaoskampf}

Gunkel bespreek in besonderhede die geveg tussen Marduk en Tiamat en hoe dit weerspieël word in talle plekke in die Bybel as 'n geveg tussen JHWH en die seemonster ${ }^{56}$. Volgens Gunkel was die chaosmite steeds teenwoordig in Israel maar die mitologiese figure van monsters het in 'n groot mate weggeval. Die mite het waarskynlik in himniese vorms in Israel bestaan. Elemente van hierdie himnes kom nog voor in die Bybel in himniese vorms.

Die water en duisternis wat aan die begin in Genesis 1 bestaan het, is chaossimbole wat algemeen voorkom in literatuur van die $\mathrm{Ou}$ Nabye Ooste $^{57}$. Die feit dat God nie volgens Genesis 1 die duisternis geskape het nie, dui vir Gunkel op 'n mitologiese oorblyfsel.

Die skeiding van die water bo en die water onder herinner aan die feit dat Marduk die seemonster Tiamat oopgekloof het en van die een helfte die hemel gemaak het en van die ander helfte te aarde. Gunkel wys op die 
ooreenkoms tussen die naam Tiamat en die Hebreeuse woord Selms ontken 'n etimologiese verband tussen die twee woorde ${ }^{59}$. Tog is die ooreenkoms tussen die voorstellings opvallend.

In Jesaja 51:9-16 en Psalm 74:12-17 vind ons 'n duidelike voorbeeld van die vermenging van die oorspronklike Chaoskampf en die verlossing uit Egipte. In Jesaja word hierdie beeld oorgedra op die verlossing uit die ballingskap. Die Chaoskampf funksioneer dus op drie vlakke. Dit is opvallend dat die weergawe in Jesaja 51 ter selfdertyd kontemporêr is asook antiek ${ }^{60}$. Die motief word in verband gebring met die situasie waarin die volk verkeer in Jesaja se tyd, maar die chaosmotief word uitgebeeld in woorde wat sterk herinner aan die Babiloniese weergawe ${ }^{61}$.

Die Chaoskampf funksioneer in Psalm 89 op 'n ander manier. Die oorspronklike mite word hier aangehaal (verse 10-11), maar die toepassing is kontemporêr. JHWH, die oorwinnaar oor die chaosmonster, is die Skepper van die kosmos maar ook die persoon wat struktuur en sekuriteit gee. Hy vestig die reg en die koningshuis van Dawid. Die Dawidiese koning sal self triomfeer oor die chaosmagte (vers 26)62. In Psalm 93 word die oorwinning oor die waters in verband gebring met die sekuriteit van JHWH se heerskappy en die setel van sy heerskappy, naamlik die heiligdom ${ }^{63}$.

In Psalm 104 word die seemonster Leviatan genoem as lid van die bewoners van die see. Dit is ironies dat die vreesaanjaende monster hier voorgestel word as troeteldier waarmee JHWH speel ${ }^{64}$. Ook aan die begin van die psalm is daar trekke van die Chaoskampf. Volgens vers 7 is die chaosmag onderdanig aan JHWH. Hy perk dit in (verse 8-9, vgl ook Job 26:10; 38:10v; Jer 5:22). Die water word volgens vers 10 (en volgende) diensbaar gemaak aan die res van die skepping65. In die psalm word die mag van God as skeppergod besing. Deur groot wysheid en mag word alles georden. Alles in die skepping is afhanklik van God (vgl verse 2730). Binne so ' $n$ ordening kan die goddelose nie bly bestaan nie (vgl vers 35). Die mens kan alleen God se lof besing66. In Psalm 104 word die skepping nie as afgehandel beskou nie, dit is 'n creatio continua. God is steeds besig om te onderhou en in stand te hou ${ }^{67}$.

\subsection{Natuurwetenskaplike voorstellings}

Dit mag vreemd voorkom dat daar in hierdie artikel 'n paragraaf kan wees met so 'n eienaardige opskrif. Hierdie opskrif impliseer nie dat die Bybelse kosmogonieë ewige natuurwetenskaplike inligting bevat nie. Dit sou egter verkeerd wees om te beweer dat die skrywers die inhoud van die kosmogonieë as suiwer metafories bedoel het. Hulle het ook die fisiese wêreld bestudeer en deur middel van induksie, deduksie en analogie tot sekere 
gevolgtrekkings gekom. 1 Konings 4:33 wys dat Israel geïnteresseerd was in die natuur. Ook in Genesis 1 is daar duidelike aanduidings van belangstelling in naturlike prosesse.

Lig was die eerste skeppingshandeling. Daardeur het die verloop van dag en nag ontstaan. God het dus aan die begin tyd geskep. Op die tweede dag het hy die vertikale ruimtedimensie geskep en op die derde dag die horisontale ruimtedimensie. Tyd en ruimte het dus aan die begin tot stand gekom. Dit klink byna modern. Tog is tyd en ruimte menslike denkkategorieë wat benut word om enige proses te verstaan. Dit is nie vreemd dat dit prominent is in menslike modelle van die begin van die kosmos nie.

Navorsers redeneer oor die diskrepansie dat daar lig was (lank) voordat die hemelliggame geskape is. 'n Gewilde verklaring is dat die volgorde van skeppingsdae nie letterlik opgeneem moet word nie, maar dat dit 'n parodie is op die Babiloniese voorstelling dat die hemelliggame gode is wat vir die skepping verantwoordelik is. ' $n$ Eenvoudige verklaring is dat hierdie voorstelling klop met verskynsels wat waargeneem word met die wisseling van nag en dag. Die skepping word vergelyk met dagbreek. Voordat die son sigbaar is in die oggend, word die hemelruim verkleur deur die eerste lig. Daarna word die aarde sigbaar en nog later kom die son op. Die feit dat die nag daar is voordat die dag breek, ondersteun ook die opvatting dat die chaos bestaan het voordat God begin het met die skepping. Dit lyk na 'n logiese prosedure om patrone wat op mikrovlak waargeneem word, ook op makrovlak toe te pas.

'n Voorstelling kan ter selfdertyd mitologies en "wetenskaplik" wees, dit wil sê die produk van logiese beredenering van sintuiglike waarnemings. Die tem van die watervoed in Genesis 1 is so 'n voorbeeld. In Genesis 1 is dit deel van die oerchaos wat in toom gehou word deur God. Die funksie van water in Genesis 1 kan ook vergelyk word met die toestande in Mesopotamië waar die lente 'n einde bring aan die oorstromings en die vrugbare alluviale neerslae blootlê.

Die beeld van die aarde wat (self) gras voortbring, was waarskynlik deel van die antieke verstaan van die natuur, so ook die klassifikasie van plante in vers 12 en die klassifikasie van diere in vers 25 . Waarheid omtrent die skepping het nie net te doen met teologiese refleksie nie, maar ook met sintuiglike waarneming en logiese beredenering. Die skrywers van Genesis het kennis geneem van die stand van die wetenskap in hulle tyd. Hulle het daardie gegewens ernstig geneem en dit saam met hulle geloofsoortuiging geïntegreer in een koherente verstaan van die kosmos. Ons kan hieruit ' $\mathrm{n}$ les leer. $\mathrm{Al}$ is die gegewens waarmee ons werk nie meer dieselfde as dit waarmee hulle gewerk het nie, kan ons hulle voorbeeld 
volg deur moderne kosmogoniese modelle te integreer met ons geloof in die Skepper68.

\subsection{Die funksie van die teks}

Dit is belangrik om te vra wat die teks met die leser behoort te doen. Inligting word nie net interessantheidshalwe gegee nie - dit het 'n doel, dit wil die leser in beweging bring. Die leser word aktief betrokke by die aktualisering van die teks.

Die eerste woorde in Genesis 1 is nie so duidelik as wat dit voorkom

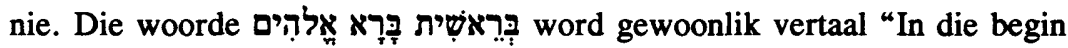
het God ... geskep". Die eerste woord is egter gevokaliseer as 'n pregenitiewe constructus-vorm wat 'n nomenale vorm sou antisipeer. Dit sou beter wees indien die tweede woord dan as ' $n$ infinitief constructus gevokaliseer word, naamlik sִּ sodat dit as 'n dubbele genitiefvorm gelees word en as 'n temporele bysin geïnterpreteer word. In die middeleeue het die Joodse geleerdes Abraham Ibn Ezra (1167) en Rashi (1105) dit so verstaan. Rashi het verse 1 tot 3 soos volg geïnterpreteer:

Toe God begin het om die hemel en die aarde te skep

temporele bysin

(die aarde was egter in chaos en die gees van God het gesweef oor die water)

neweskikkende temporele bysin

het God gesê...

hoofsin

In Ezra het dit só gelees:

Toe God begin het om die hemel en die aarde te skep

temporele bysin

was die aarde in chaos en die gees van God het gesweef oor die water en God het gesê...

hoofsin

Die ander moontlike manier van vokalisering is om die eerste woord van

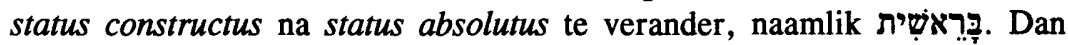
word dit vertaal:

In die begin het God die hemel en die aarde geskep; hoofsin 
en die aarde was in chaos...

hoofsin

Laasgenoemde lesing kan ook geïnterpreteer word dat die eerste reël 'n opskrif is (Westermann bespreek hierdie moontlikhede in besonderhede in sy kommentaar ${ }^{69}$ :

In die begin het God die hemel en die aarde geskep.

$$
\text { opskrif }
$$

Die aarde was in chaos...

hoofsin

Walther Eichrodt argumenteer op 'n oortuigende manier dat die eerste reël 'n absolute begin moet veronderstel en dus as 'n hoofsin gelees moet word ${ }^{70}$. Dit ondersteun die creatio ex nihilo-konsep. Die moontlikhede wat Rashi en Ibn Ezra voorstaan, verteenwoordig nie 'n absolute begin nie. Laasgenoemde moontlikhede veronderstel dat die chaos reeds bestaan het toe God begin het om te skep. God het dus die chaos as roumateriaal gebruik en deur 'n proses van ordening die geordende kosmos geskep. Beide voorstellings het voetangels. Eichrodt se voorstelling veronderstel dat God die skepper van die chaos is - iets wat moeilik denkbaar is in die lig van die assosiasie tussen die chaos en die mitologiese chaosmonster en die Chaoskampf wat op die agtergrond lê. Aan die ander kant veronderstel die twee rabbi's se voorstel dat God se skepping nie 'n absolute begin was nie en dus nie 'n creatio ex nihilo nie. Iets van die pre-eksistensie van die chaos kom hier voor soos in die ou mites uitgebeeld. 'n Mens wonder of die Masorete nie doelbewus die vokalisering van die teks dubbelsinnig gemaak het omdat hulle ook nie kon kies tussen hierdie moontlikhede nie! Indien dit die geval is, laat dit ons met 'n verrassende moontlikheid: Die Bybel gee aan die leser die reg om besluite te neem oor die interpretasie van die begin. Een van twee teenoorgestelde opsies kan gekies word, terwyl albei in beginsel geakkommodeer word.

Die voorstelling dat die aarde binne 'n "borrel" in die chaosmonster se buik bestaan met chaos aan alle kante, moes die mens van destyds onder die indruk bring dat die lewe riskant is. Die wêreld bestaan in en deur die genade van God ${ }^{71}$. Die feit dat God rus aan die einde van die skepping, bewys dat $\mathrm{Hy}$ alles onder beheer het ${ }^{72}$. In Genesis 1:1-2:3 word die skepping as 'n harmonieuse geheel geskets. Dit word onderstreep deur God se evaluasie: Dit is baie goed (vers 31 ). Hierdie toestand van harmonie is net moontlik solank as wat God dit in stand hou. Sodra Hy die perke wat 
Hy aan die chaosmagte gestel het, verslap, is daar weer wanorde soos by die sondvloed (Gen 7:11). Volgens die oerverhaal in Genesis, beweeg die skepping op die rant van terugkeer na chaos as gevolg van geweld van mense. Dit het reeds eenmaal plaasgevind met die sondvloed. Die goeie nuus is dat God weer na so 'n toestand van chaos 'n herskepping kan bewerkstellig73. Die bestaan van chaos in die lewe word erken. God het daaraan plek gegee in sy raadsplan. Tog kan ons in die troos lewe dat God dit inperk en aan ons 'n leefruimte gee waarbinne ons geluk kan vind. Dit is ook die strekking van Job 38:4-11. Daar word gesê dat God aan die aarde sowel as die see 'n plek gee. God het egter perke aan die see gestel.

Die beeld van 'n wêreld wat omring word deur chaos, word interessant voorgestel in Job 26:7:

Hy sprei die Noorde uit oor die chaos

hy hang die aarde op oor die "niks"

In Egiptiese mitologie moet die songod Ra elke oggend Apofis verdryf. So 'n mite kom nie in die Bybel voor nie. Tog keer die motief van die oorwinning oor die chaos weer en weer terug. Die verblyf in Egipte en die Babiloniese ballingskap word in die Bybel in verband gebring met die Chaoskampf. Dit impliseer dat God telkens oorwinning gee oor die chaos, of dit terugkeer in die vorm van die Egiptenare of in die vorm van die Babiloniërs ${ }^{74}$. Genesis 1 is waarskynlik tydens die ballingskap geskryf. Die beeld van 'n borrel binne chaos sou treffend pas by die volk se omstandighede in die ballingskap.

Die feit dat God die skepping telkens beoordeel en "goed" bevind, ja, selfs "baie goed" na die skepping van die mens, dui daarop dat die skepping waardeer en geniet behoort te word. Daar is skoonheid in die skepping wat gewaardeer en gerespekteer moet word. Elke ding is gemaak om te pas. Daar is in die volgorde van die dae ook 'n patroonmatigheid: In die eerste drie dae is die domeine geskep van dit wat in die volgende drie dae geskep sou word ${ }^{75}$. Daar is 'n doelmatigheid in die skepping. Vanuit 'n religieuse perspektief funksioneer die teleologiese beginsel sterk in die skepping.

'n Doelbewuste ontmitologisering vind plaas. Die hemelliggame word nie eers by hulle name genoem nie - dit sou te veel herinner aan die Babiloniese gode. Hier is die hemelliggame blote lampe (Gen 1:16-17). In

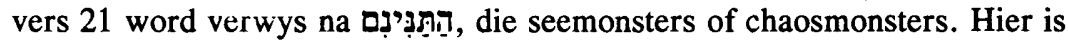
dit seediere soos al die ander. Hierbo is aangetoon hoe die oorspronklike chaosmite nog in poëtiese tekste in die Ou Testament behoue gebly het. In 
Genesis 1 is dit in 'n groot mate ontmitologiseer. Die ontmitologiseringsproses sien ons ook by die verandering van 'n politeïsme na 'n monoteïsme. Die oorspronklike mite veronderstel 'n aantal gode. In Genesis $1: 26,3: 22$ en $11: 7$ bly die voorstelling van 'n hemelse raad, maar dit is nie gode op dieselfde vlak as God nie ${ }^{76}$. Die meervoudsvorme in die uitspraak: "Laat ons mense maak na ons beeld..." (Gen 1:26) dui op 'n voorstelling van 'n hemelse raad wat saam die besluit neem (vlg Psalm 89:7, Psalm 82:1, 1 Kon 22:19-22; Jes 6; Job 1; Dan 7:10; Henog 14:22-23; Openb 4).

Die voorstelling dat die hemelliggame heers, kom ook uit die antieke tyd. Volgens Jesaja 40:26 is die sterre magtige heersers. 'n Magtige koning word met 'n ster vergelyk (Num 24:17; Jes 14:12). Sterre het 'n invloed op die aarde (Job 38:7), mense is oorgelewer tot diens aan die sterre (Deut 4:19). Die sterre kry 'n goddelike karakter. Hulle word sterre van God genoem (Jes 14:13), hulle is selfs hemelwesens (Rig 5:20; Jes 24:21; Job 38:7). Volgens Henog 82 is die sterre heersers oor seisoene ${ }^{77}$. In Genesis 1 vind ons 'n drastiese aanpassing van die tradisie. Die hemelliggame het nie meer gesag soos in die Babiloniese godsdiens nie, maar bepaal net seisoene. Die son, maan en sterre word nie eers by die naam genoem nie, daar word net na hulle verwys as "ligte". Die hemelliggame is nie van altyd af daar nie - hulle word eers op die vierde dag geskape.

Die feit dat man en vrou na die beeld van God geskep is, verhef die verhouding van man en vrou tot een van die basiese boustene van die lewe. Die mens se heerskappy oor die skepping word toegeskryf aan 'n besonder seëning van God. Dit is ook 'n verantwoordelikheid wat op die mens se skouers geplaas is. Hierdie seën en verantwoordelikheid is vandag steeds geldig 78 .

Die verdeling in 7 dae is waarskynlik 'n latere konsep wat toegepas is op 'n ouer siening van die volgorde van die skeppingsmomente. Volgens Gunkel ${ }^{79}$ het hierdie samesmelting van meer as een stelsel veroorsaak dat die kronologie nie heeltemal logies is nie. Die sewedeling hou verband met die week as eenheid en is toegespits op die viering van die sewende dag, naamlik die Sabbat. Die priesters het met die skeppingsverhaal probeer om die basiese boustene van die lewe in verhaalvorm uit te beeld. Die sabbat is ook deel van die basiese boustene van die lewe.

\section{GEVOLGTREKKING}

Die kosmogonieë van die Bybel kan nie as wetenskaplike modelle geld nie. Dit is ' $n$ totaal ander modus van kommunikasie. Anderson som dit soos volg op: 
It is another question altogether, however, as to whether this language, which is set in a mythopoeic context and which serves a doxological purpose, is related to the scientific view of the origination of the world in a hash of light, like a cosmic hydrogen explosion, at a sharply defined instant some sixteen billion years ago. Mythopoeic language cannot be converted into scientific language any more than poetry can be reduced to prose. It is hard to see how creationists can divest the creation story of its God-centered language and can propose teaching it, theologically denuded, as an alternative to a scientific hypothesis. Mythopoeic language provides a different approach to reality via the faculty of poetic intuition or imagination. While this approach may coexist with, and even be compatible with, the scientific method with its methodological limitations, it is questionable whether the two languages say the same things. The scientist is concerned with description and control and is neutral about meaning, while the theologian is concerned with ultimate meaning and purpose. The scientist speaks of contingency (chance), whereas the theologian perceives that the earth and everything in it belongs to God and depends upon God constantly. The scientist may speak of a first cause in a chain of events, but the theologian declares that God, who transcends the whole cause-effect scheme, created the cosmos in freedom ${ }^{80}$.

Die vraag of die kosmos 'n absolute begin en einde het, is nie van deurslaggewende belang vir die teologie nie. Al sou die kosmos sonder grens wees, maak dit nie inbreuk op God se domein nie. Wanneer daar in religieuse terme van ewigheid gepraat word, is dit 'n heel ander konsep as oneindigheid op die tydsas van 'n ruimte-tyd-matriks. Al sou die tydsas van die kosmiese ruimte-tyd-matriks sonder begin of einde wees, maak dit vir die gelowige geen verskil aan die feit dat God die kosmos geskep het nie.

Die verband tussen oorsaak en gevolg is meer kompleks as wat 'n mens dink. Die natuurwetenskap verklaar verskynsels vanuit 'n oorsaak wat dit voorafgegaan het. Indien tyd 'n dimensie is soos ruimte binne 'n ruimte-tyd-matriks, is die rigting van tyd nie noodwendig net in een rigting nie. Hawking vra in die verbygaan die vraag: Waarom onthou ons die verlede maar nie die toekoms nie? Die voor-die-hand-liggende antwoord is: Omdat die verlede reeds gebeur het en die toekoms nog nie. Is die pyl van die tyd noodwendig net in een rigting gerig? Dit lyk so volgens natuurwette soos die tweede wet van termodinamika. Tog is daar aspekte van die werklikheid wat volgens ons waarneming aan sekere natuurlike beperkinge 
ondergeskik is, maar in werklikheid bestaan die beperkinge in die bewussyn van die mens. Een voorbeeld van die beperkinge van die bewussyn is die bestaan van meer dimensies as drie. Die mens kan vir homself net drie dimensies voorstel, maar in sy wiskunde hou hy rekening met 'n onbeperkte aantal dimensies. Dit mag gebeur dat daar eendag ook binne 'n natuurwetenskaplike model ruimte gemaak word vir die teleologiese beginsel, naamlik dat daar 'n verband bestaan tussen 'n verskynsel en die doel waarheen dit beweeg (nie net die oorsaak nie). God se betrokkenheid by die proses kan alleen vanuit 'n teologiese perspektief bespreek word en kan nooit deel vorm van 'n natuurwetenskaplike model nie.

In die Bybelse kosmogonieë is daar nie 'n probleem om die teleologiese beginsel te aanvaar nie - om die waarheid te sê - dit is 'n kernelement. Daar is 'n doel in die lewe. God het die kosmos geskape met 'n doel. Die patroon van die ses skeppingsdae illustreer dat dit wat in die eerste drie dae geskape is, plaasgevind het met die oog op dit wat in die volgende drie dae sou gebeur. Binne ons konteks is dit geldig om te sê dat God die aangrypende big bang op hierdie spesifieke manier laat plaasvind het sodat ek en u vandag hier kan wees. Die Bybel gaan verder deur te sê dat God dit gedoen het omdat Hy vir ons lief is en vir ons wil sorg. Soos met die big bang het God ook 'n doel met elke mens se lewe!

Die chaosmite word in die Bybel reeds metafories gebruik om die mens se stryd op aarde voor te stel. Ek kan aan geen beter metafoor dink om ons omstandighede mee uit te beeld nie. Tog illustreer God se oorwinning oor die chaosmagte die feit dat God ook oorwinning, orde en 'n nuwe skepping in mense se lewens kan bewerkstellig. Die mens rebelleer teen die teenwoordigheid van die chaos, maar is dankbaar vir die feit dat dit reeds oorwin is en deur God ingeperk is.

Daar moenie neergesien word op die mitologiese aspekte van Bybelse kosmogonieë nie. Vandag kan die mens die Hubbleteleskoop gebruik om ver in die verlede van die kosmos in te kyk - tot byna by die begin. Vir die antieke mens was mites die teleskoop waardeur hulle kon terugkyk in die verlede - hulle was oorgelewer aan voorstellings uit die verre verlede. Daar is egter ook ' $n$ belangrike aspek van mites wat in gedagte gehou moet word. Mites slaan nie net op die verlede nie, maar op die tydlose wese van die werklikheid en die wese van die mens. Dit moet egter in 'n nuwe tydsgewrig nuut vertaal word. Dit is inderdaad wat in Genesis 1 gebeur.

'n Mens moenie uit die veld geslaan wees indien daar gegewens in Bybelse kosmogonieë is wat verrassend naby kom aan moderne modelle nie. Modelle het te doen met menslike denke en menslike waarneming. 'n Model is nie ' $n$ beeld van die werklikheid nie, maar ' $n$ beeld van die mens 
se verstaan van die werklikheid. Dit kan verwag word dat dieselfde denkkategorieë by verskillende mense sal voorkom al is hulle in tyd ver van mekaar verwyderd. Ons menswees maak kommunikasie tussen ons moontlik. Indien die ooreenkomste tussen natuurwetenskaplike bevindinge en Bybelse modelle op die spits gedryf word om die gesag van die Bybel te bevestig, gaan die argument die doel ondermyn. Die verskille tussen die modelle is veel groter as die ooreenkomste.

Dit moet nooit weer nodig wees vir 'n Copernicus of Galileo om te huiwer om natuurwetenskaplike bevindinge bekend te maak nie. Die gelowige kan ook 'n goeie natuurwetenskaplike wees. Selfs die bestudering van die big bang en wat dit voorafgegaan het (as daar tyd voor die big bang bestaan het), hou geen bedreiging in vir die soewereiniteit van God nie. Die big bang is nie meer of minder heilig as saad wat ontkiem nie.

Die vraag of die natuurwette ruimte laat vir 'n verskeidenheid van moontlikhede en of dit noodwendighede veronderstel, is ook nie kritiek vir die geloof in God se ingryping nie. God werk deur die naturwette wat Hy geskep het, of, as Hy wil, buite die natuurwette. God se optrede word nie deur die bestaan van reëlmatighede of die afwesigheid daarvan, deur natuurwetenskaplike sekerhede of onsekerhede, geïnhibeer nie. Dit wil egter voorkom asof alle gebeure in die kosmos in modelle geakkommodeer kan word. Dit wat ons as wonders beskou, kan ook 'n natuurwetenskaplike dimensie hê wat binne 'n natuurwetenskaplike model "verklaar" kan word. So is daar ook ' $n$ religieuse dimensie in die kosmiese gebeure, ja, selfs in daardie gebeure wat binne 'n naturwetenskaplike model verklaar kan word. Dit lyk asof dit 'n wesenskenmerk van die mens se kennende omgaan met die werklikheid is dat enige model ook die element van misterie moet kan akkommodeer. Die element van misterie dui nie op 'n goddelike aspek van die model nie. Dit is nie meer of minder heilig as dit wat netjies pas binne wetenskaplike modelle nie. Die element van misterie dui op die begrensdheid van die mens se kenvermoë.

Naïwiteit en wetenskaplikheid is nie wedersyds uitsluitend nie. Wanneer die kosmos deur middel van natuurwetenskaplike strategieë ontleed word, kan die element van aangryping soveel groter wees. Vir die gelowige sal die fynlees van die kosmos die vingermerke van die Skepper duideliker na vore bring. Tog pas hierdie waarneming nie in 'n natuurwetenskaplike model nie. Die waarnemer het dan die wetenskaplike terrein verlaat. Waar natuurwetenskaplike modelle wetmatighede identifiseer, funksioneer aangryping op 'n estetiese en religieuse vlak. Waar die Bybel oor die kosmos praat, val dit in die meeste gevalle op laasgenoemde vlak.

Die ontwikkelinge op natuurwetenskaplike gebied is opwindend, so ook die ontwikkelinge op teologiese gebied. 'n Natuurwetenskaplike 
kosmogonie het miskien nie 'n Skepper nodig nie, maar die mens wat dit ontwerp ... het.

Self die moderne natuurwetenskap kan die gelowige lei tot 'n religieuse ervaring waar hy of sy in ekstase uitroep:

O Here, ons Here, hoe wonderbaar is u Naam oor die hele aarde, $\mathrm{U}$ wat $\mathrm{u}$ heerlikheid gelê het oor die hemel!

\section{NOTAS:}

1 A Peacocke, God and science. A quest for Christian credibility, Londen 1996, 6.

2 C W Du Toit, The contribution of Arthur Peacocke to the science-theology debate, in: Du Toit, C W (red), Nature, God and humanity, Pretoria 1996, 84 101.

$3 \quad$ Peacocke, $a w, 1996$.

4 A Peacocke, Theology for a scientific age. Being and becoming - natural, divine and human, London 1990.

5 A Peacocke, The sciences and theology in the twentieth century, Stocksfield 1981.

$6 \quad$ Peacocke, $a w, 1996,3$.

7 W B Drees, Beyond the big bang. Quantum cosmologies and God, La Salle 1993, 156.

8 L Gilkey, Religion and the scientific future, Londen 1970, 66.

9 Gilkey, $a w, 1970,77$.

10 T F Torrance, "Divine and contingent order", in: Peacocke, A (red), The sciences and theology in the twentieth century, Stocksfield 1981, 95-9.

11 Drees, $a w, 175$.

12 Drees, $a w, 175$

13 Drees, $a w, 193$.

14 E McMullin, "How should cosmology relate to theology?" in: Peacocke, A (red), The sciences and theology in the twentieth century, Stocksfield 1984, 19.

15 McMullin, $a w, 19-20$.

16 McMullin, $a w, 21$.

17 McMullin, $a w, 29$.

18 McMulli, $a w, 40$.

19 McMullin, $a w, 22-24$.

20 McMullin, $a w, 30$.

21 S Hawking, A brief history of time (tweede uitgawe), Londen 1996, 9.

22 McMullin, $a w, 17,30$.

23 Kyk McMullin, $a w, 30$.

24 McMullin, $a w, 31$.

25 McMullin, $a w, 32$.

26 Kyk L Gilkey, Maker of heaven and earth, New York 1959.

27 Kyk R Jastrow, God and the astronomers, New York 1980, 105-106.

28 Kyk Hawking, $a w, 48-49$. 
Hawking, $a w, 49$.

30 Kyk Hawking, $a w, 49$.

31 Hawking, $a w, 138-139$

J W Kane \& M M Sternheim, Physics (derde uitgawe), New York 1988, 50. W Pannenberg, "Theological questions to scientists", in: A Peacocke (red), The sciences and theology in the twentieth century, Stocksfield.

34 Torrance, $a w, 96$.

35 McMullin, $a w, 40$.

36 Kyk Drees, $a w, 60-62$.

$37 \quad$ Kyk Peacocke, $a w, 1996,17$.

38 Peacocke, $a w, 1996,17-19$.

39 Hawking, $a w, 144$.

40 McMullin, $a w, 44$.

41 Peacocke, $a w, 1996,19-22$.

42 Hawking, $a w, 140$.

43 Kyk Hawking, $a w, 50-54$.

44 Hawking, $a w, 152-160$.

45 Hawking, $a w, 161$.

$46 \quad$ Kyk McMullin, $a$ w, 39.

47 Peacocke, $a w, 1996,11-13$.

48 H Gunkel, Schöpfung und Chaos in Urzeit und Endzeit: Eine religionsgeschichtliche Untersuchung über Gen 1 und Ap Joh 12, Göttingen 1895.

49 B W Anderson, Creation versus chaos: The reinterpretation of mythical symbolism in the Bible, New York 1967.

50 R J Clifford \& J J Collins, "The theology of creation traditions", in: R J Clifford \& J J Collins (reds), Creation in Biblical traditions, pp 1-15, Catholic Biblical Quarterly Monograph Series 24, 1992b, 15.

51 H \& H A Frankfort, The intellectual adventure of ancient man: An essay in speculative thought in the Ancient Near East, Chicago 1946. Kyk B W Anderson (red), Creation in the Old Testament, Londen 1984, 3.

S3 Clifford \& Collins, $a w, 1992 b, 9-10$.

54 V H Matthews \& D C Benjamin, Old Testament parallels: laws and stories from the ancient Near East, New York 1991.

H Gunkel, "The influence of Babylonian mythology upon the Biblical creation story", in: B W Anderson (red), Creation in the Old Testament, 25-52, Londen 1984, 47.

Gunkel, $a w, 1895,30-82$.

Gunkel, $a w, 1984,26$.

Gunkel, $a w, 1984,45$.

Kyk A Van Selms, Genesis deel 1, Nijkerk 1967, 23.

Kyk C Westermann, Isaiah 40-66 (OTL), Londen 1980, 239-242.

1 Kyk J B Pritchard, Ancient Near Eastern texts relating to the Old Testament, Princeton 1955, 67.

2 Kyk H-J Kraus, Psalmen. 2. Teilband Psalmen 60-150, Neukirchen-Vluyn 1978, 793.

Kyk Kraus, $a w, 820$.

64 Kraus, $a w, 884$. 
65 Kraus, $a w, 882$.

66 Kraus, $a w, 887$.

67 Anderson, $a w, 1984,14$.

68 Kyk T Fretheim, "Genesis 1:1-11:26 Overview", in: L E Keck et al (reds), The new interpreter's Bible (volume I), 335-338, Nashville 1994, 337.

69 C Westermann, Genesis Kapitel 1-11 (Biblischer Kommentar altes Testament), Neukirchen-Vluyn 1976, 131-135.

70 W Eichrodt, "In the beginning: A contribution to the interpretation of the first word of the Bible”, in: B W Anderson (red), Creation in the Old Testament, Londen 1984, 65-73.

71 Kyk B F Batto, "Creation theology in Genesis", in: R J Clifford \& J J Collins (reds), 1992a, Creation in Biblical traditions, 16-38, Catholic Biblical Quarterly Monograph Series 24, 1992, 33.

$72 \quad$ Kyk Batto, $a w, 33$.

$73 \quad$ Anderson, $a w, 1984,18$.

$74 \quad$ Kyk Batto, $a w, 34$.

$75 \quad$ Kyk Van Selms, $a w, 42$.

76 Gunkel, $a w, 1984,28-29$.

77 Kyk Gunkel, $a w, 1984,27-28$.

78 Gunkel, $a w, 1984,30$.

79 Gunkel, $a w, 1984,31$.

80 Anderson, $a w, 1984,17-18$. 